\title{
Penile Soft Tissue Neoplasm
}

National Cancer Institute

\section{Source}

National Cancer Institute. Penile Soft Tissue Neoplasm. NCI Thesaurus. Code C162574.

A rare primary mesenchymal neoplasm in the penis. 